\title{
40. PETROGRAPHY AND AGE OF QUARTZ-MUSCOVITE-CHLORITE SEMISCHIST, SITE 281, SOUTH TASMAN RISE
}

\author{
A. T. Ovenshine, Béla Csejtey, Jr., and James G. Smith, U.S. Geological Survey, \\ Menlo Park, California \\ and \\ Peter B. Andrews, New Zealand Geological Survey, Christchurch, New Zealand
}

\begin{abstract}
Drilling at Site 281 on the South Tasman Rise recovered fragments of carbonaceous quartz-muscovite-chlorite semischist. The schist was developed by very low-grade regional metamorphism (greenschist facies) of a sedimentary rock that was poorly sorted and quartz rich. An average of two whole-rock potassium-argon ages of the semischist is $306 \pm 10 \mathrm{~m} . \mathrm{y}$. Analysis of the drilling record strongly suggests that semischist bedrock was reached at 159.5 meters and was penetrated to a depth of 169.0 meters. The results establish the continental nature of the crust underlying the South Tasman Rise.

The semischist at Site 281 may correlate with the CambrianPrecambrian Robertson Bay Group of northern Victoria Land, Antarctica. A reconstruction of the Australo-Antarctic part of Gondwanaland that places the South Tasman Rise near Victoria Land leads to significant overlap in the Ross Sea area. Following the suggestion of Hayes and Ringis (1973), this overlap can be eliminated by restoring approximately $400 \mathrm{~km}$ of left lateral movement between east and west Antarctica.
\end{abstract}

\section{INTRODUCTION}

One of the objectives of drilling at Site 281 was to recover samples of acoustic basement from the South Tasman Rise. The rise is an approximately $800-\mathrm{km}$-long southeast-trending submarine landform located south of Tasmania. The South Tasman Rise, which rises to within 900 meters of sea level above the ocean floor 4000 meters or more in depth, is separated from the continental shelf of Tasmania by a pronounced but complicated saddle whose highest point is approximately 1500 meters below sea level (Hayes and Conolly, 1972, fig. 1). The composition of the crust underlying the South Tasman $\mathrm{R}$ ise is a factor in formulating preseparation reconstructions of the Antarctic and Australian plates: presumably fewer complications would arise in the fit of Tasmania into Antarctica if the Rise were a postseparation volcanic edifice rather than continental crust that had survived the rifting process.

Fragments of quartz-muscovite semischist recovered from the deepest cores have been studied petrographically, and the semischist has been dated by the potassium-argon method. The purpose of this report is to present data derived from these studies, discuss the basement drilling, and interpret the results in light of the continental fragmentation of Australia and Antarctica.

\section{DRILLING AT SITE 281}

The semischist encountered was not recovered as solid core segments. The interpretation that basement was reached and penetrated is based mainly on the drilling record.
The plot shown in Figure 1 relates depth of the bit below sea level during the drilling against the time at which the core was brought aboard Glomar Challenger. Hence Figure 1 shows the core recovery rate. Although the variables plotted could show major influences from several factors, generally the major influence on the core recovery rate at any one site is the true drilling rate. The true drilling rate, in turn, is principally a function of the characteristics of the rock being penetrated.

For most of the subbottom penetration the core recovery rate was approximately $13 \mathrm{~m} / \mathrm{hr}$. At 1760.5 meters (159.5 m subbottom), however, the rate diminished to $2-3 \mathrm{~m} / \mathrm{hr}$. This change strongly suggests that bedrock was being drilled. That bedrock was reached at approximately 159.5 meters is consistent with the first recovery of semischist fragments in Sample 17, CC. (159.5 m subbottom).

Our interpretation, therefore, is that semischist basement was drilled between 159.5 and 169.0 meters subbottom. T' a poor core recovery probably resulted from (1) equipment failure or blockage of the opening of the core barrel (see operations section, Site 281 Site Report, Chapter 8 , this volume), or (2) drilling comminution of the schist along the closely spaced planes of schistosity, followed by washing of the fragments during the retrieval of the core.

\section{UNCONSOLIDATED SEMISCHIST BRECCIA}

Except for fragments of semischist in Samples 17, CC and $18, \mathrm{CC}$, the deepest recovery at Site 281 is $130 \mathrm{~cm}$ of unconsolidated breccia interlayered with silt and clay contained in Core 17, Section 6. The greenish-gray sedi- 


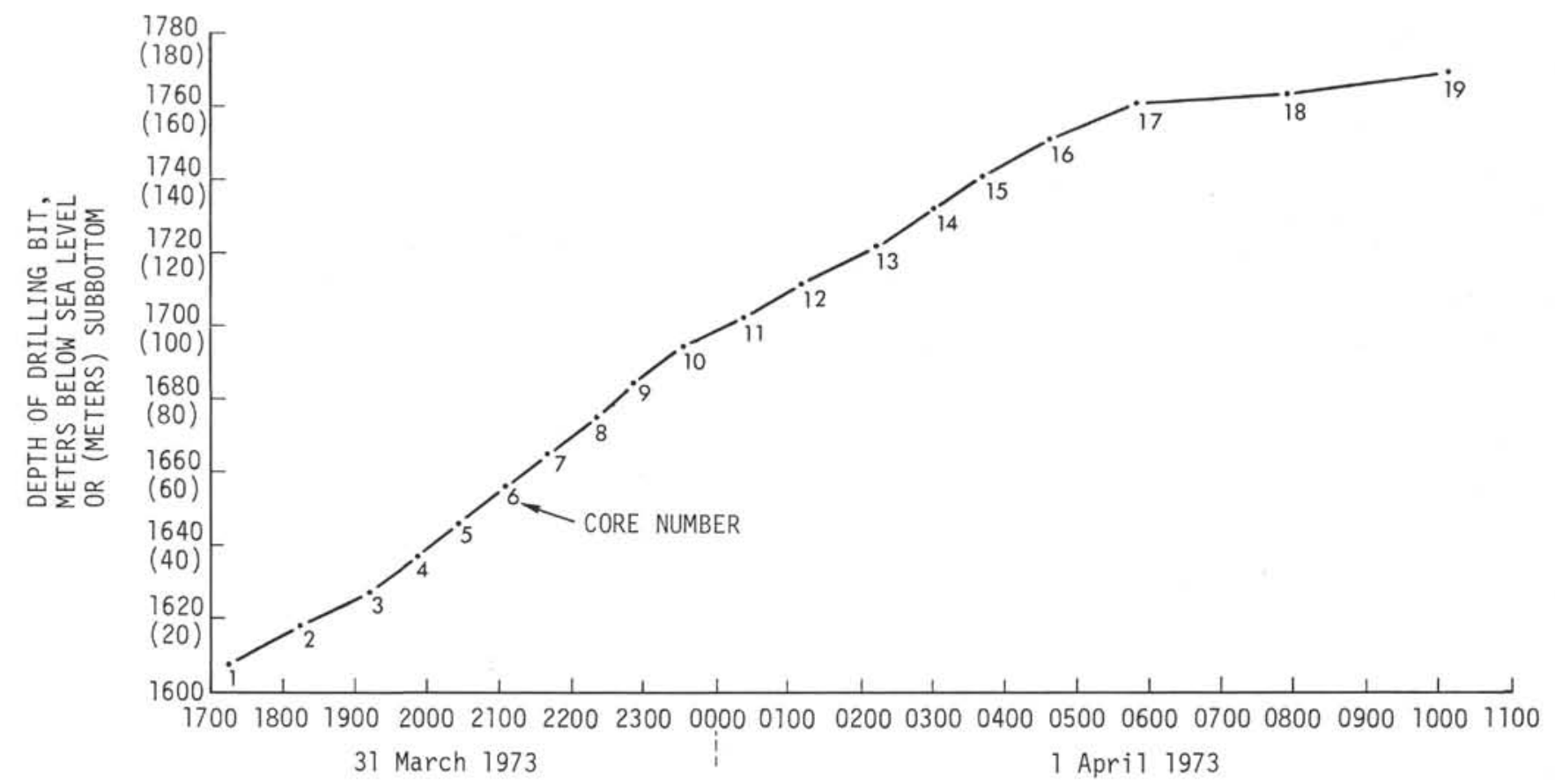

Figure 1. Plot of core recovery rate for Site 281. The marked decrease in rate at Core 17 (159.5 m subbottom) is interpreted as the upper surface of the semischist bedrock.

ment, which apparently overlies the semischist bedrock, consists of coarse sand, granules, and rare small pebbles of unweathered semischist (65\%), quartz and quartzite (15\%), glauconite $(15 \%)$, glauconitic sandstone $(5 \%)$, and traces of granitic rocks. Rare late Eocene benthonic foraminifera occur in the finer parts of the sediment.

The glauconitic unconsolidated breccia is interpreted as a shallow-water "basal conglomerate" recording late Eocene transgression and submergence, between the upper surface of the semischist bedrock $(159.5 \mathrm{~m}$ subbottom), and the glauconite-bearing detrital sand and foraminifera-rich nannofossil chalk at the top of Core 17 (150-150.5 m subbottom).

\section{PETROGRAPHY OF THE SEMISCHIST}

Sample 29-281-17, CC is clearly a metamorphic rock, classified here as a quartz-muscovite-chlorite semischist. Although the sample consists of only a few small rock chips, each about $4 \mathrm{~cm}$ in maximum dimension, it is considered representative of a larger rock unit, because of the uniform petrography of the semischist.

In hand specimen the semischist is a fine-grained, highly schistose, medium-gray rock with a bluish tint. Of its mineral components, only flakes of muscovite along the schistosity planes can be distinguished with the unaided eye. The schistosity in the chips is straight, and without any obvious deformation.

Studies of three thin sections indicate the semischist consists of quartz and muscovite in elongate grains up to $0.4 \mathrm{~mm}$ in maximum dimension. These are, more or less, evenly distributed in a finer grained schistose matrix of quartz, chlorite, muscovite, scattered opaque grains of leucoxene-covered ilmenite, and a few streaks of carbonaceous material, probably graphite (Figure 2). A small irregular crystal with high relief and faint pleochroism, probably tourmaline, was also observed. Xray diffraction studies failed to disclose the presence of additional rock forming minerals.

The larger, elongate quartz grains, a small portion of which are composite grains, are subangular to subrounded, parallel or subparallel with the schistosity, and all have strained extinction. These quartz grains form an estimated one-fourth of the rock by volume and appear to be relict clastic grains.

The large muscovite grains are mostly undeformed and parallel or subparallel to the schistosity. A few of these mu scovite grains, however, are bent or broken and occupy positions nearly perpendicular to the schistosity. While the parallel muscovite grains are clearly lepidoblastic metamorphic minerals, the deformed and perpendicular crystals may possibly represent relict clastic mica grains.

The finer grained matrix, with an average grain size between 0.1 and $0.05 \mathrm{~mm}$, consists of a highly schistose mosaic of sutured quartz with undulating extinction, lepidoblastic flakes of muscovite, and elongate prisms and needles of light green chlorite. The chlorite crystals are too fine grained to determine their optical properties. Presence of carbonaceous material in the rock was substantiated by heavy liquid mineral separation, using diluted bromoform with a specific gravity of 2.61 .

The texture of the semischist is schistose, with relict clastic components of the original parent rock. Thus, the 


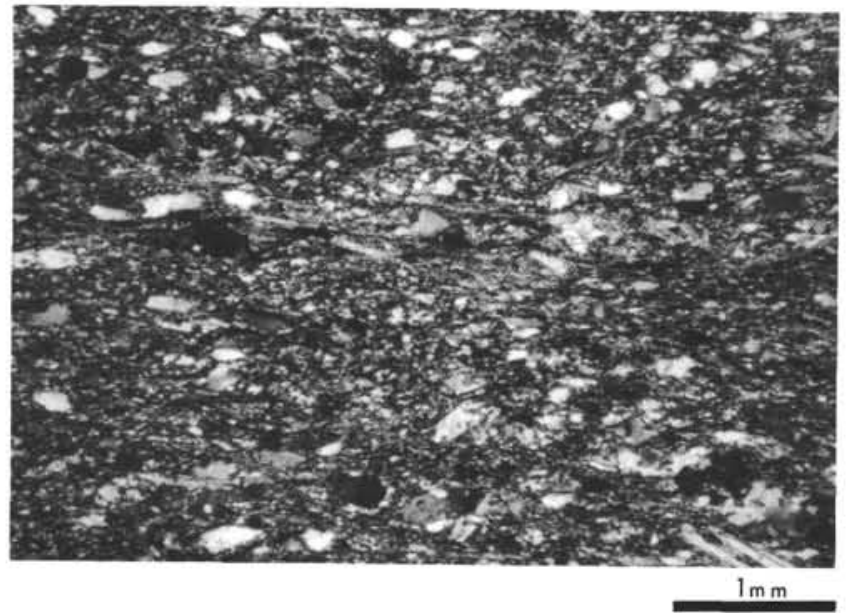

Figure 2. Photomicrograph of semischist from Site 281, South Tasman Rise. Elongate, subangular to subrounded crystals of strained quartz and lepidoblastic muscovite in a schistose matrix of quartz, muscovite, chlorite, and subordinate carbonaceous material. Crossed nicols.

TABLE 1

Potassium-Argon Analyses of Sample 29-281-17, CC ${ }^{\text {a }}$

\begin{tabular}{lccccc}
\hline Fraction & $\begin{array}{c}\mathrm{K}_{2}{ }^{0} \\
(\%)\end{array}$ & $\begin{array}{l}{ }^{40} \mathrm{Ar}_{\mathrm{rad}} \\
\left(10^{-10} \text { moles/g) }\right.\end{array}$ & & ${ }^{40}{ }_{\mathrm{Ar}_{\mathrm{rad}}}$ & \\
\hline Fine & 2.03 & 9.998 & & $\begin{array}{c}\text { Apparent Age } \\
\text { (m.y.) }\end{array}$ \\
Coarse & 1.79 & 8.739 & & 0.88 & $307 \pm 8$ \\
\hline
\end{tabular}

Note: Constants used in age determinations are $\lambda_{\epsilon}=0.585 \times$ $10^{-10} \mathrm{yr}^{-1} ; \lambda_{\beta}=4.72 \times 10^{-10} \mathrm{yr}^{-1} ;{ }^{40} \mathrm{~K} / \mathrm{K}$ total $=1.19 \times$ $10^{-4}$ moles/mole.

${ }^{\mathrm{a}}$ Argon analyses by James $\mathrm{G}$. Smith; $\mathrm{K}_{2} \mathrm{O}$ analyses by Lois Schlocker.

texture indicates a transitional phase in the regional metamorphic evolution of a clastic rock into mica schist.

On the basis of the metamorphic mineral assemblage and texture, the semischist belongs to the low-grade portion of the greenschist metamorphic facies of Turner (1968). Textural features and mineralogical composition suggest that the semischist evolved from a fine-grained, quartz-rich, possibly micaceous clastic rock, such as a poorly sorted siltstone or graywacke.

\section{POTASSIUM-ARGON AGES}

Separate K/Ar determinations were made on each of two size fractions obtained by crushing and sieving a 5-g sample composed of approximately 20 individual chips. The coarse fraction was composed of particles between 0.495 and $0.354 \mathrm{~mm}$ and hopefully would contain more of the large muscovite grains which are oriented perpendicular to the foliation. The fine fraction was composed of particles finer than $0.354 \mathrm{~mm}$. We reasoned that if the larger muscovite flakes were in part inherited from a premetamorphic rock, and if their $\mathrm{K} / \mathrm{Ar}$ clocks were not completely reset by metamorphism, then the coarser fraction should be significantly older than the fine fraction (Tabor, 1972).

The argon analyses were made by standard isotopedilution techniques on a Neir-type 6 -inch radius $60^{\circ}$ sector mass spectrometer in the U.S. Geological Survey Laboratories in Menlo Park, California. The potassium analyses were made with a flame photometer using a lithium internal standard. The precision of the ages is reported as \pm values, which have been assigned on the basis of experience with replicate analyses and uncertainties in the individual runs. The value represents the cumulative uncertainties in the argon and potassium analyses, in isotopic composition, in concentration of the Ar tracer, and in concentration of the flame photometer standards. In general, the uncertainties average about $3 \%-4 \%$ of the calculated age. The analytical data and calculated ages are shown in Table 1.

The measured ages of the two fractions are the same within the experimental error of the method and indicate that the coarser mica is not relict. If it is, its $\mathrm{K} / \mathrm{Ar}$ clock has been completely reset.

\section{DISCUSSION}

In many reconstructions of the Australo-Antarctic part of Gondwanaland, Tasmania is placed near to northern Victoria Land in Antarctica (Sproll and Dietz, 1969, fig. 3, Griffiths, 1971, fig. 3; Solomon and Griffiths, 1972, fig. 3; Hayes and Ringis, 1973, fig. 7). The results of our investigations of the semischist from Site 281 can be interpreted to support a geological correlation between the South Tasman Rise and northern Victoria Land. This correlation, however, raises some problems in the plate-tectonic interpretation of the region.

The rocks at Site 281 may correlate with the late Precambrian-Cambrian (American Geographical Society, 1969) Robertson Bay Group (Harrington et al., 1967) of northern Victoria Land, Antarctica. The principal similarities, based on published descriptions, are: (1) semischist of low metamorphic grade developed from graywacke (Harrington et al., 1967, p. 22) and (2) relict clastic grains composed predominantly of quartz (Crowder, 1968, p. D97), although there are local exceptions (Sturm and Carryer, 1970, p. 420-421). Crowder's description (p. D97), derived from a helicopter reconnaissance of a large part of northern Victoria Land, may be the most generally representative of the Robertson Bay Group.

"Dark to light gray, brownish gray and greenish gray rocks, particularly fine grained semischists predominate. (They are composed of) poorly sorted angular to subangular clasts, mostly quartz, in a sericitic and chloritic matrix of recrystallized argillaceous material. A volcanic detrital component has not been recognized..."

Previous workers have correlated the Robertson Bay Group with the Precambrian metasediments of western Tasmania (Griffiths, 1971, p. 206; Crawford and Campbell, 1973, fig. 3). 
The 306 m.y. whole-rock potassium-argon age of the sample from Site 281 is younger than whole-rock ages from the Robertson Bay Group (410 and 420 m.y., American Geographical Society, 1969). Post-kinematic granitic plutons, however, invade both the Robertson Bay Group (Admiralty Intrusives, Harrington, 1958) and the Precambrian of western Tasmania (McDougall and Leggo, 1965). These plutons have undoubtedly changed the original age of large areas of country rock. In both Tasmania and Victoria Land the granitic rocks are late Devonian to early and possibly middle Carboniferous in age (375-335 m.y. in Tasmania, McDougall and Leggo, 1965; 385-300 m.y. in Victoria Land, Sturm and Carryer, 1970). Possibly the 306 m.y. age of the rocks at Site 281 reflects mainly the age of the mid-Paleozoic post-kinematic plutons.

Although Hayes and Ringis (1973, fig. 7) are notable exceptions, most reconstructions of the AustraloAntarctic part of Gondwanaland have not dealt with the South Tasman Rise, because it could be assumed to be a postseparation volcanic edifice in the absence of the data obtained by drilling at Site 281 . For example, the pre-Tertiary construction of Sproll and Dietz (1971, fig. 3), reproduced here as Figure 3, does not allow room for the $800-\mathrm{km}$-long South Tasman Rise. Thus the continental crustal composition of the rise yields significant overlap in the vicinity of the Ross Sea and Iselin Plateau. In Figure 4 the South Tasman Rise has been sketched on the reconstruction shown in Figure 3, with areas of overlap indicated by cross-hatching.

Hayes and Ringis (1973, p. 458) speculate that the overlap of the South Tasman Rise can be explained by restoring approximately $400 \mathrm{~km}$ of post-Late Cretaceous left-lateral motion of east and west Antarctica along a line passing west of the Iselin Plateau. Presumably a fault of this magnitude would cut across the Antarctic Continent along the subglacial topographic low between the Ross and Ronne Ice shelves. Our geologic correlation between the South Tasman Rise and Victoria Land would seem to support the idea of Hayes and Ringis (1973), although we would place the hypothetical fault trace closer to the Adare Peninsula than to the Iselin Plateau.

\section{REFERENCES}

American Geographical Society, 1969. Geologic map of northern Victoria Land, Antarctica. In Bushnell, V. C. (Ed.), Antarctic map folio series: Am. Geogr. Soc., scale 1:1,000,000.

Crawford, A. R. and Campbell, R. S. W., 1973. Large-scale horizontal displacement within Australo-Antarctica in the Ordovician: Nature Phys. Sci., v. 241, p. 11-14.

Crowder, D. F., 1968. Geology of a part of North Victoria Land, Antarctica: U.S. Geol. Survey Prof. Paper 600-D, p. D95-D107.

Griffiths, J. R., 1971. Reconstruction of the South-West Pacific margin of Gondwanaland: Nature, v. 234, p. 203207.

Harrington, H. J., 1958. Nomenclature of rock units in the Ross Sea region, Antarctica: Nature, v. 182, p. 290.

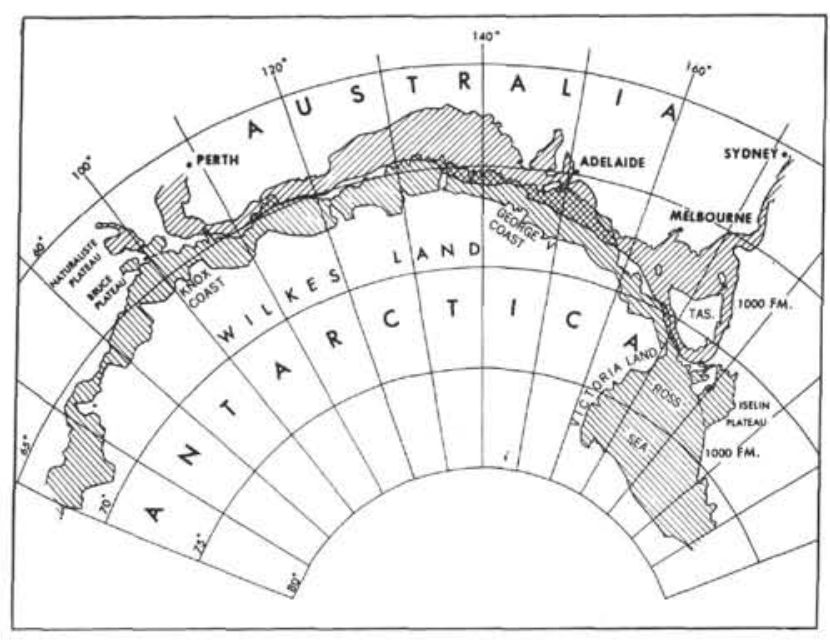

Figure 3. Australo-Antarctic reconstruction of Sproll and Dietz (1969, fig. 3). The ruled pattern signifies the continental shelf and slope to the 1000 fathom isobath. Cross-hatch pattern indicates areas of overlap; blank areas indicate underlap.

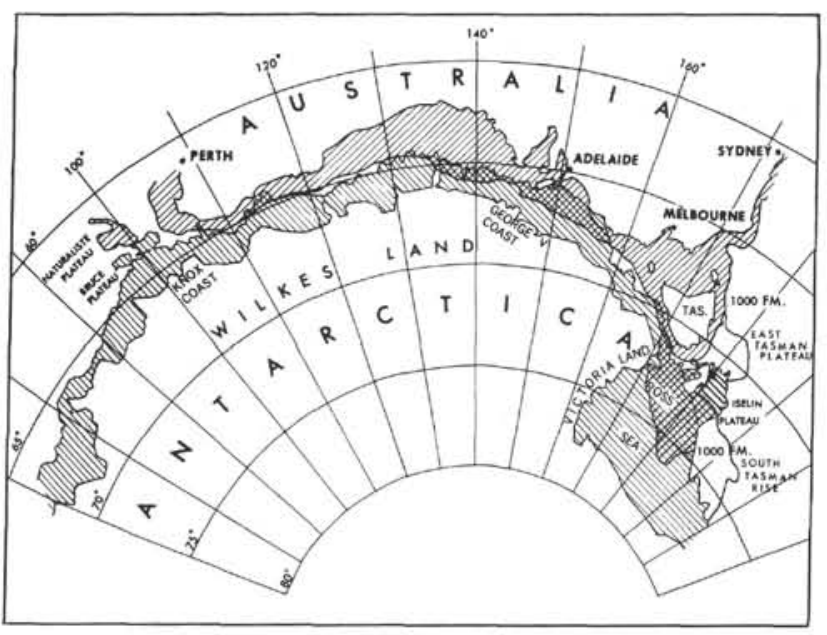

Figure 4. Reconstruction of Sproll and Dietz (1969, fig. 3) on which we have sketched the outline of the South Tasman Rise and the East Tasman Plateau. Major areas of overlap (indicated by cross-hatch pattern) occur in the Ross Sea.

Harrington, H. J., Wood, B. L., McKellar, I. C., and Lensen, G. J., 1967. Topography and geology of the Cape Hallett District, Victoria Land, Antarctica: New Zealand Geol. Surv. Bull. n.s. 80.

Hayes, D. E. and Conolly, J. R., 1972. Morphology of the Southeast Indian Ocean. In Hayes, D. E. (Ed.), Antarctic oceanology, II The Australia-New Zealand sector: Am. Geophys. Union, Antarctic Res. Ser., v. 19, p. 125-146.

Hayes, D. E. and Ringis, J., 1973. Sea floor spreading in the Tasman Sea: Nature, v. 243, p. 454-458. 
McDougall, I. and Leggo, P. J., 1965. Isotopic age determinations on granitic rocks from Tasmania: J. Geol. Soc. Australia, v. 12, p. 295-332.

Solomon, M. and Griffiths, J. R., 1972. Tectonic evolution of the Tasman Orogenic Zone, eastern Australia: Nature Phys. Sci., v. 237, p. 3-6.

Sproll, W. P. and Dietz, R. S., 1969. Morphological continental drift fit of Australia and Antarctica: Nature, v. 222, p. 345-348.
Sturm, A. and Carryer, S. J., 1970. Geology of the region between the Matusevich and Tucker Glaciers, North Victoria Land, Antarctica: New Zealand J. Geol. Geophys., v. 13, p. 408-435.

Tabor, R. W., 1972. Age of the Olympic metamorphism, Washington: $\mathrm{K}-\mathrm{Ar}$ dating of low-grade metamorphic rocks: Geol. Soc. Am. Bull., v. 83, p. 1805-1816.

Turner, F. J., 1968. Metamorphic petrology, mineralogical and field aspects: New York (McGraw-Hill). 